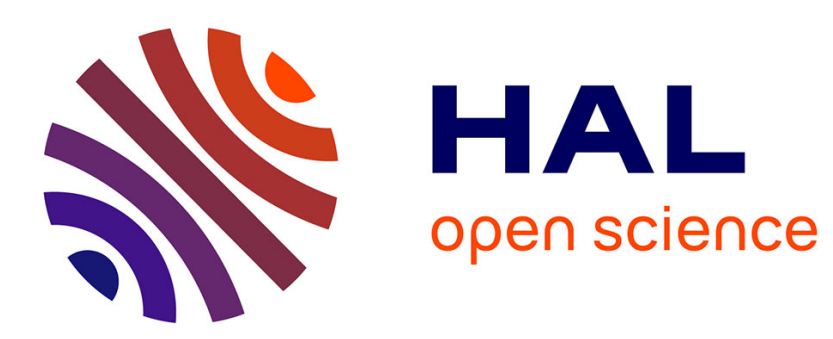

\title{
Valorization of coarse rigid polyurethan foam waste in lightweight aggregate concrete
}

\author{
Amor Ben Fraj, Mohamed Kismi, Pierre Mounanga
}

\section{To cite this version:}

Amor Ben Fraj, Mohamed Kismi, Pierre Mounanga. Valorization of coarse rigid polyurethan foam waste in lightweight aggregate concrete. Construction and Building Materials, 2010, 24 (6), pp.10691077. 10.1016/j.conbuildmat.2009.11.010 . hal-01007420

\section{HAL Id: hal-01007420 \\ https://hal.science/hal-01007420}

Submitted on 13 Oct 2017

HAL is a multi-disciplinary open access archive for the deposit and dissemination of scientific research documents, whether they are published or not. The documents may come from teaching and research institutions in France or abroad, or from public or private research centers.
L'archive ouverte pluridisciplinaire HAL, est destinée au dépôt et à la diffusion de documents scientifiques de niveau recherche, publiés ou non, émanant des établissements d'enseignement et de recherche français ou étrangers, des laboratoires publics ou privés. 


\title{
Valorization of coarse rigid polyurethane foam waste in lightweight aggregate concrete
}

\author{
Amor Ben Fraj, Mohamed Kismi, Pierre Mounanga* \\ GeM, UMR CNRS 6183 - Research Institute on Civil Engineering and Mechanics, University of Nantes - IUT Saint-Nazaire, 58 rue Michel Ange, \\ BP 420, F-44606 Saint-Nazaire cedex, France
}

\begin{abstract}
This study examines the mechanical properties and the durability parameters of lightweight aggregate concretes (LWAC) incorporating rigid polyurethane (PUR) foam waste as coarse aggregates (8/20 mm). The influence of both the increasing incorporation of PUR foam waste and the presence of superplasticizer on the workability, bulk density, mass loss, drying shrinkage, compressive strength, dynamic modulus of elasticity, total porosity, gas permeability and chloride diffusion coefficient of the different concretes, has been investigated and analyzed. The results showed that the use of PUR foam waste enabled to reduce by 29-36\% the dry density of concrete compared to that of the normal weight concrete (made without foam waste). The reduction of density was due to the increase of total porosity in the lightweight concretes, which also induced higher gas permeability and chloride diffusion coefficient. These negative effects on durability of concrete were lowered by improving the characteristics of the cementitious matrix. The mechanical properties of the LWAC ranged between 8 and $16 \mathrm{MPa}$ for the compressive strength and between 10 and 15 GPa for the dynamic modulus of elasticity; the concrete mixture with the higher per-formances almost satisfied the mechanical and density criteria of structural lightweight concrete. These results consolidate the idea of the use of PUR foam waste for the manufacture of lightweight aggregate concretes.
\end{abstract}

\section{Keywords:}

Lightweight aggregate concrete

Polyurethane foam waste

Compressive strength

Permeability

Shrinkage

Chloride diffusion

\section{Introduction}

The use of lightweight aggregates (LWA) in concrete presents many positive aspects. Kayali [1] recently summarized these benefits: The low-density of concrete induced by the lightweight aggregates enables to reduce dead load of structures, footings sizes and dimensions of columns, slabs and beams. It results in larger space availability in buildings. Costs of transport and handling equipment for pre-cast elements are also reduced. Besides, the low heat transfer properties of lightweight aggregate concrete (LWAC) provide higher thermal insulation and may improve fire resistance.

Two kinds of low-density aggregates used in lightweight concrete may be distinguished: natural aggregates (pumice, diatomite, volcanic cinders, etc.) and artificial aggregates (expanded perlite, shale, clay, slate or glass, hollow microspheres, expanded polystyrene or other polymer materials, plastic granules, etc.). Artificial aggregates may be obtained through specific industrial processes or come from waste or by-products. Numerous studies have been performed on the valorization of industrial waste (lightweight

\footnotetext{
* Corresponding author. Tel.: +332 401781 89: fax: +332 40178160 .

E-mail address: pierre.mounanga@univ-nantes.fr (P. Mounanga).
}

crushed bricks [2], incinerator bottom ash [3], scrap tires [4-6], plastic waste [7-9], lignite power generation residues [10]) or vegetable by-products (wood chipping [11], oil palm shell [12], flax by-product [13]) for the manufacture of lightweight concrete. According to their origin (mineral, vegetable or industrial) and properties, these lightweight aggregates influence the fresh and hardened properties of concrete in a specific way. Even if a chemical, mechanical or thermal pre-treatment of these waste is sometimes necessary [13-15], the majority of the studies concluded that the use of solid waste as lightweight aggregate constituted an interesting way to valorize them.

In the field of plastics, alveolar foam waste represents a considerable percentage of the annually produced plastic waste volume [16]. They are used as combustibles [17] or incorporated in industrial manufacturing composite processes $[18,19]$. Although scarce research works were published on the subject, the incorporation of plastic foam waste for the manufacture of lightweight concretes could also constitute an interesting alternative [20,21].

A previous study [22] focused on the thermal properties of concrete made with the fine and medium fractions of rigid polyurethane (PUR) foam waste particles $(0-10 \mathrm{~mm})$. The present work concerned the development and the characterization of lightweight concretes made with the coarse part of the PUR-foam 
aggregates, ranging between 8 and $20 \mathrm{~mm}$. The mechanical properties and the durability parameters of four PUR foam lightweight aggregate concretes and a normal weight concrete, as the control

Table 1

Chemical composition and physical properties of cement.

\begin{tabular}{lc}
\hline Compounds & \% (by weight) \\
\hline $\mathrm{CaO}$ & 64.35 \\
$\mathrm{SiO}_{2}$ & 20.20 \\
$\mathrm{Al}_{2} \mathrm{O}_{3}$ & 4.85 \\
$\mathrm{Fe}_{2} \mathrm{O}_{3}$ & 2.80 \\
$\mathrm{MgO}_{\mathrm{SO}}$ & 0.90 \\
$\mathrm{Na}_{2} \mathrm{O}$ & 3.05 \\
$\mathrm{~K}_{2} \mathrm{O}$ & 0.16 \\
Loss on ignition & 0.98 \\
$\mathrm{Residue}$ insoluble & 1.65 \\
$\mathrm{Active}$ alkali & 0.22 \\
$\mathrm{Free} \mathrm{lime}$ & 0.80 \\
$\mathrm{Blaine}$ fineness (m & $2 / \mathrm{kg})$ \\
Density (-) & 1.30 \\
Main compounds (Bogue's equation) \% by weight & 339 \\
$\mathrm{C}_{3} \mathrm{~S}$ & 3.16 \\
$\mathrm{C}_{2} \mathrm{~S}$ & \\
$\mathrm{C}_{3} \mathrm{~A}$ & 62.01 \\
$\mathrm{C}_{4} \mathrm{AF}$ & 11.13 \\
Gypsum & 8.11 \\
\hline
\end{tabular}

Table 2

Gradation of fine and coarse aggregates.

\begin{tabular}{lll}
\hline \multirow{2}{*}{ Sieve size $(\mathrm{mm})$} & \multicolumn{2}{l}{ Accumulated passing $(\%)$} \\
\cline { 2 - 3 } & Fine aggregate & $\begin{array}{l}\text { Coarse normal and } \\
\text { lightweight aggregate }\end{array}$ \\
\hline 20 & - & 100 \\
16 & - & 97 \\
14 & - & 92 \\
12.5 & - & 61 \\
10 & - & 11 \\
8 & - & 3 \\
6.3 & 100 & - \\
5 & 99.2 & - \\
2.5 & 86.8 & - \\
1.25 & 68.9 & - \\
0.63 & 45.9 & - \\
0.315 & 14.7 & - \\
0.16 & 1.5 & - \\
0.08 & 0.2 & - \\
\hline
\end{tabular}

Table 3

PUR foam LWA properties.

\begin{tabular}{llllll}
\hline $\begin{array}{l}\text { Specific } \\
\text { gravity } \\
\left(\mathrm{kg} / \mathrm{m}^{3}\right)\end{array}$ & $\begin{array}{l}\text { Bulk } \\
\text { density } \\
\left(\mathrm{kg} / \mathrm{m}^{3}\right)\end{array}$ & $\begin{array}{l}\text { Porosity } \\
(\%)\end{array}$ & $\begin{array}{l}\text { Water } \\
\text { absorption in } \\
\text { volume }(\%)\end{array}$ & $\begin{array}{l}\text { Compressive } \\
\text { strength }(\mathrm{kPa}) \\
\text { for a deformation } \\
\text { of } 10 \%\end{array}$ & $\begin{array}{l}\text { Young's } \\
\text { modulus } \\
(\mathrm{MPa})\end{array}$ \\
\hline 45 & 21 & 98 & 13.9 & 174 & 5.6 \\
\hline
\end{tabular}

material, have been measured. In order to maintain a comparable aggregate size distribution between the various concretes, the initial PUR foam waste was sieved to reconstitute a particle size distribution curve identical to that of the $8 / 20-\mathrm{mm}$ siliceous coarse aggregates used for the manufacture of the control concrete. The experimental work was aimed at analyzing the influence of both the increasing incorporation of PUR foam coarse aggregate and the presence of superplasticizer on the workability, bulk density, mass loss, drying shrinkage, compressive strength, dynamic modulus of elasticity, total porosity, gas permeability and chloride diffusion coefficient of the different concretes. Scanning electron microscope (SEM) observations were also carried out in order to examine the morphology of the interfacial zone between the cementitious matrix and the lightweight aggregates.

\section{Experimental study}

2.1. Materials

2.1.1. Cement, normal weight aggregates and superplasticizer

The cement used in this study is CEM I $52.5 \mathrm{~N}$ from Saint Pierre La Cour plant (France). Its chemical composition and main physico-chemical properties are detailed in Table 1.

The sand is a river sand $0 / 6.3 \mathrm{~mm}$ with a specific gravity of $2580 \mathrm{~kg} / \mathrm{m}^{3}$ and a water absorption coefficient of $0.90 \%$ (in mass). The coarse aggregates are siliceous gravel $8 / 20 \mathrm{~mm}$ (specific gravity: $2590 \mathrm{~kg} / \mathrm{m}^{3}$ and water absorption: $0.49 \%$, in mass). The particle size distributions of both fine and coarse aggregates are given in Table 2.

A polycarboxylate-based superplasticizer (SP) was added to the concretes with lower water-to-cement ratio in order to reduce the amount of mixing water needed and improve their workability. In liquid form, it has a specific gravity of $1050 \mathrm{~kg} / \mathrm{m}^{3}$ and a dry content of $20 \%$.

\subsubsection{PUR foam lightweight aggregates}

The lightweight aggregates (LWA) incorporated in concrete are coarse particles $(8-20 \mathrm{~mm})$ of PUR foam waste. Table 3 provides their main physical and mechanical properties. It should be noted that PUR foam is a very compressible material compared to the other concrete components (cement, water, sand and gravels): its density can thus vary according to the pressure exerted. The water absorption of LWA was determined after $24 \mathrm{~h}$ of immersion. Concerning mechanical properties, three cubic rigid PUR foam specimens were tested on a Zwick $50 \mathrm{kN}$ universal testing machine at $20^{\circ} \mathrm{C}$, and the values obtained were averaged. The specimen dimensions were $50 \mathrm{~mm} \times 50 \mathrm{~mm} \times 50 \mathrm{~mm}$ and the speed of crosshead movement was $5 \mathrm{~mm} / \mathrm{min}$

The LWA were sieved in order to separate them into five different size ranges (Table 2). This operation facilitated the mixture proportioning of lightweight concretes by rigorously controlling the coarse aggregate gradation. The aggregates larger than $20 \mathrm{~mm}$ were not taken into account in this study. A previous study [22] focused on the finest part of foam waste $[0-10 \mathrm{~mm}]$. Here, the smallest lightweight aggregates used corresponded to the particles retained on the 8-mm sieve (Table 2).

\subsection{Concrete mixtures}

Four lightweight aggregate concretes (LWAC-1; LWAC-1sat; LWAC-2sat and LWAC-3sat), incorporating PUR-foam aggregates, and a normal weight concrete (NWC), as control material, were prepared. The mix proportions of the five concretes manufactured are detailed in Table 4. The LWA used for the preparation of LWAC-1 sat, LWAC-2sat and LWAC-3sat mixes were immersed in water for $24 \mathrm{~h}$ before mixing to improve the workability of fresh concrete. The water-to-cement ratio indicated in Table 4 does not take into account the amount of supplementary water

Table 4

Mix proportions and slump values of the concretes.

\begin{tabular}{|c|c|c|c|c|c|c|c|c|c|}
\hline \multirow[t]{2}{*}{ Mix code } & \multicolumn{6}{|c|}{ Mix proportions $\left(\mathrm{kg} / \mathrm{m}^{3}\right)$} & \multirow{2}{*}{$\begin{array}{l}\text { PUR-foam volume } \\
\text { content }(\%)\end{array}$} & \multirow[t]{2}{*}{$\mathrm{W} / \mathrm{C}$ ratio } & \multirow[t]{2}{*}{ Slump values ( $\mathrm{mm})$} \\
\hline & Cement & Water & Sand & $\begin{array}{l}\text { Normal } \\
\text { aggregates }\end{array}$ & $\begin{array}{l}\text { PUR-foam } \\
\text { aggregates }\end{array}$ & SP & & & \\
\hline NWC & 397 & 220 & 824 & 867 & - & - & 0 & 0.55 & 170 \\
\hline LWAC-1 & 397 & 220 & 824 & - & 15.1 & - & 34 & 0.55 & 60 \\
\hline LWAC-1sat & 397 & 220 & 824 & - & 15.1 & - & 34 & 0.55 & 190 \\
\hline LWAC-2sat & 415 & 183 & 862 & - & 15.8 & 1.405 & 35 & 0.44 & 80 \\
\hline LWAC-3sat & 353 & 156 & 734 & - & 20.1 & 1.196 & 45 & 0.44 & 60 \\
\hline
\end{tabular}


provided by the prewetted LWA. This pre-wetting of LWA represents an addition of water of about $47 \mathrm{~kg} / \mathrm{m}^{3}, 49 \mathrm{~kg} / \mathrm{m}^{3}$ and $62 \mathrm{~kg} / \mathrm{m}^{3}$ for LWAC-1sat, LWAC-2sat and LWAC-3sat mixes, respectively.

For LWAC-2sat and LWAC-3sat mixes, the influence of a superplasticizer addition and a $20 \%$-reduction of the initial $\mathrm{W} / \mathrm{C}$ ratio compared to the control concrete was quantified. In the case of LWAC-2sat mix, PUR foam and cement contents were slightly increased, while, for LWAC-3sat mix, the cement amount was reduced and the PUR-foam aggregate content was significantly increased.

\subsection{Experimental program and testing procedures}

The slump and the fresh density of the mixtures were determined before casting the concrete in moulds. For each concrete mixture, cylindrical specimens (diameter: $11 \mathrm{~cm}$; height: $22 \mathrm{~cm})$ and prismatic specimens $(7 \times 7 \times 28 \mathrm{~cm})$ were prepared. After casting, all the specimens were moist-cured at $20 \pm 2{ }^{\circ} \mathrm{C}$ and over $90 \%$ of relative humidity for $24 \mathrm{~h}$. They were then de-moulded. The cylindrical specimens were kept in a water tank at $20 \pm 2{ }^{\circ} \mathrm{C}$ until the age of testing. The prismatic specimens were air-cured in the laboratory at $20 \pm 2{ }^{\circ} \mathrm{C}$ and $50 \pm 5 \%$ of relative humidity. The 28-day compressive strength, the total porosity and the transfer

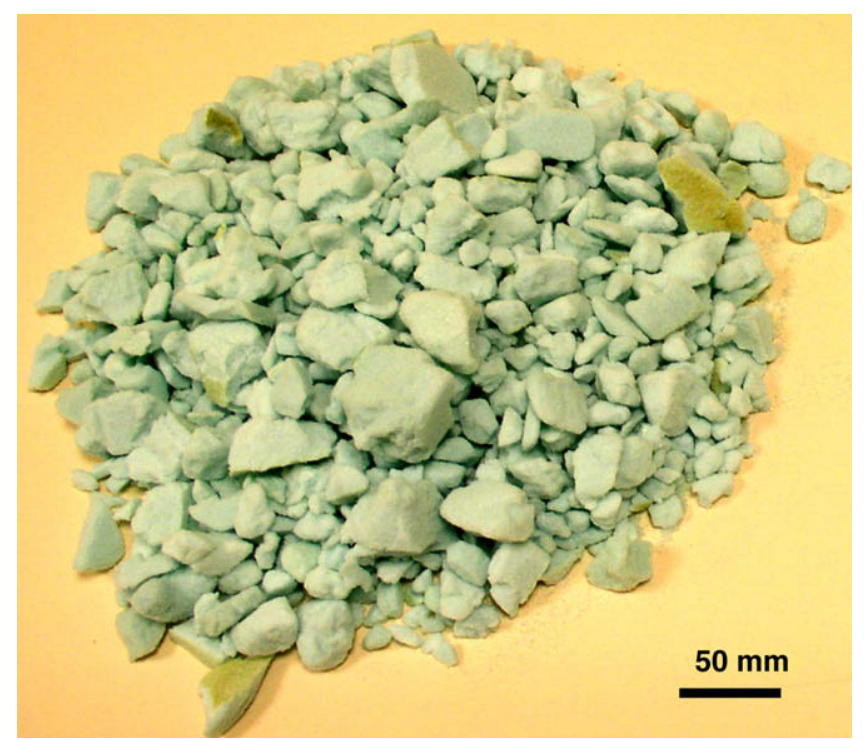

Fig. 1. Coarse PUR-foam waste. parameters (gas permeability and chloride diffusion coefficient) at 180 days were measured on cylindrical specimens. The drying shrinkage, the mass loss and the dynamic modulus of elasticity were tested on the prismatic specimens (see Fig. 1).

\subsubsection{Slump test and fresh density}

The slump test was used to quantify the workability of concrete. The wet bulk density of concrete was obtained by measuring the mass and volume of the compacted fresh concrete.

\subsubsection{Drying shrinkage and mass loss}

The drying shrinkage of $7 \times 7 \times 28$-cm concrete prisms was determined by a calibrated dial gauge (accuracy: $\pm 0.001 \mathrm{~mm}$ ). The mass loss was measured with a balance of accuracy $\pm 0.01 \mathrm{~g}$. For each concrete, the average evolution of these properties were obtained from the measurements on two specimens examined from 1 day after casting to 28 days.

\subsubsection{Mechanical properties}

The 28-day compressive strength was tested on cylindrical specimens. The dynamic modulus of elasticity was determined at 28 days on the prismatic specimens by impulse excitation tests using a Grindosonic ${ }^{\circledR}$ device. Each mechanical property value presented in the following of the article is the average value obtained from tests performed on two specimens.

\subsubsection{SEM investigation}

After the compressive tests, PUR-foam concrete fragments were observed by scanning electron microscope (SEM) using an environmental Zweiss EVO ${ }^{\circledR} 40$ system.

\subsubsection{Gas permeability}

Concrete cylinders were cut using a diamond blade saw to obtain $50-\mathrm{mm}$ thick discs with two parallel plane faces. One disc was extracted from the central portion of each cylinder (Fig. 2), polished and cleaned. Its thickness was measured with an accuracy of $0.1 \mathrm{~mm}$ and its curved surface sealed with two epoxy resin coats to ensure a one-dimensional gas flow inside the discs. Both the drying mode and the water saturation degree may have a direct influence on the gas permeability of concrete. In this study, the discs were ovendried at $40{ }^{\circ} \mathrm{C}$ during several weeks until constant mass $( \pm 0.01 \mathrm{~g})$, in order to ensure a similar moisture content for the whole specimens. Then, they were cooled for $48 \mathrm{~h}$ in a desiccator at $20^{\circ} \mathrm{C}$ before the tests.

Permeability measurements were performed using a Cembureau constant head permeameter with nitrogen as the neutral percolating gas (Fig. 3). This method consists in applying various differential pressures to the concrete disc and in measuring the steady flow of gas $Q\left(\mathrm{~m}^{3} / \mathrm{s}\right)$ passing through the specimen [23]. The apparent permeability $K_{A}\left(\mathrm{~m}^{2}\right)$ is calculated using Eq. (1), which assumes laminar flow, compressible fluid and steady state of flow:

$K_{A}=\frac{Q}{A} \cdot \frac{2 \mu \cdot L}{\left(P_{\text {inlet }}^{2}-P_{\text {outlet }}^{2}\right)} \cdot\left(\frac{T+273.15}{T_{0}+273.15}\right) \cdot P_{0}$
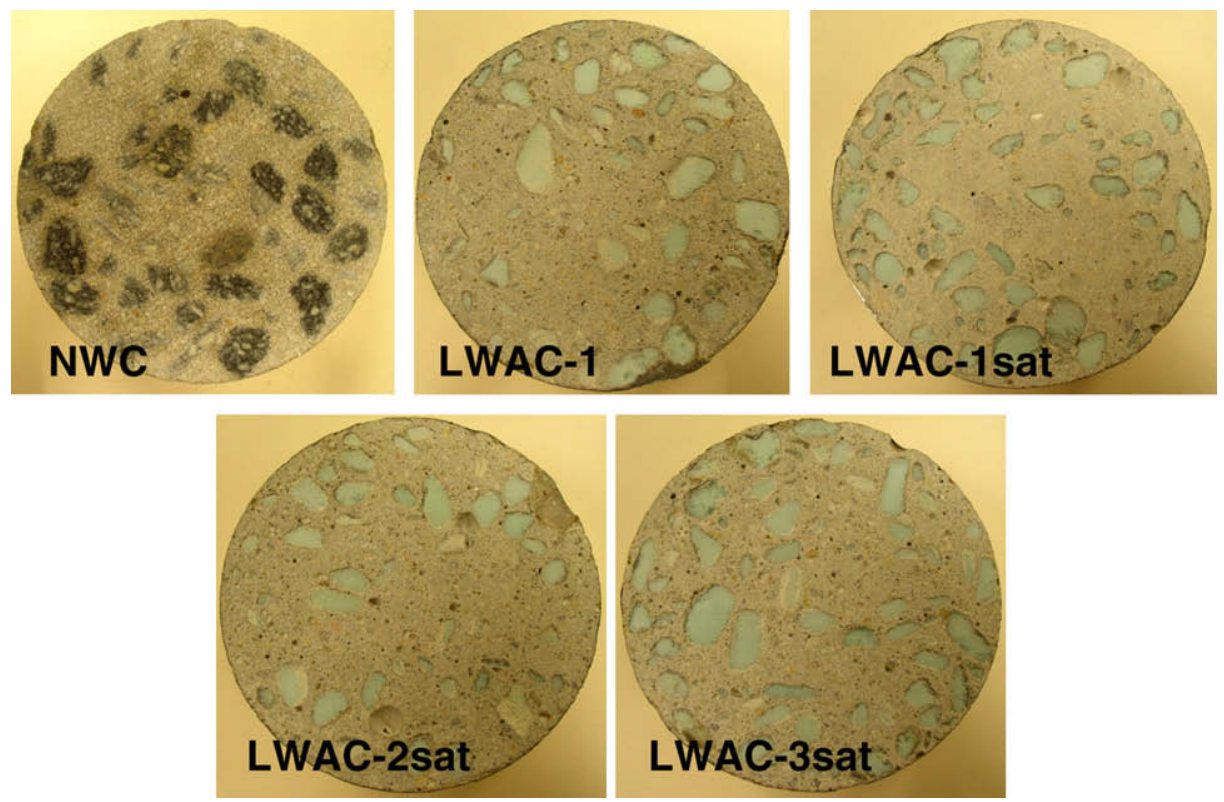

Fig. 2. Sawn cylindrical specimens of the different concretes. 


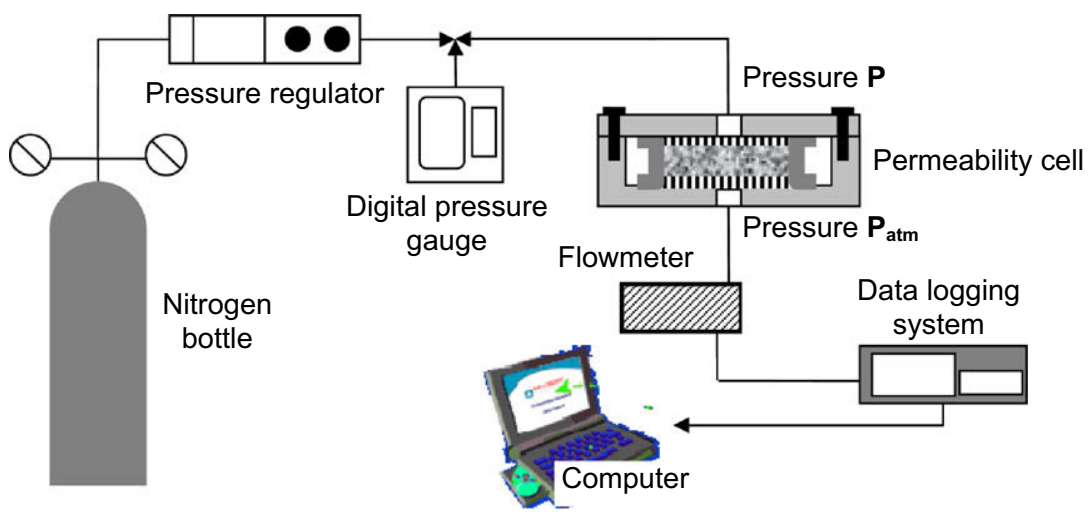

Fig. 3. Schematic layout of the experimental setup for gas permeability tests.

where $L$ is the thickness of the sample (m); $A$ is the cross-sectional area $\left(\mathrm{m}^{2}\right) ; \mu$ is the coefficient of viscosity $\left(1.78 \times 10^{-5} \mathrm{~Pa}\right.$ s for nitrogen gas at $\left.20^{\circ} \mathrm{C}\right)$; $P_{\text {inlet }}$ is the inlet pressure (Pa); $P_{\text {outlet }}$ is the outlet pressure $(\mathrm{Pa}) ; T_{0}$ and $P_{0}$ are the standard temperature $\left(0^{\circ} \mathrm{C}\right)$ and pressure $\left(1.01325 \times 10^{5} \mathrm{~Pa}\right)$, respectively; and $T$ is the ambient temperature $\left({ }^{\circ} \mathrm{C}\right)$.

The relation proposed by Klinkenberg (Eq. (2)) introduces the concept of an intrinsic coefficient of permeability $K_{V}\left(\mathrm{~m}^{2}\right)$ relative to viscous flow only:

$K_{A}=K_{V}\left(1+\frac{\beta}{P_{m}}\right)$

where $P_{m}$ is the mean gas pressure (Pa), $P_{m}=\left(P_{\text {inlet }}+P_{\text {outlet }}\right) / 2$; and $\beta$ is the Klinkenberg coefficient (Pa). In order to determine $K_{V}$, the value of $K_{A}$ is measured at various pressures $\left(P_{\text {inlet }}\right)$ and plotted as a function of the inverse of the mean pressure $\left(1 / P_{m}\right)$. From five differential pressures applied, the correlations of the linear regressions are satisfactory, with a coefficient higher than 0.99 (Fig. 4).

\subsubsection{Total open porosity}

The volume percentage of open porosity in concrete specimens can be estimated using the following equation:

$n=\frac{\left(W_{\text {sat }}-W_{\text {dry }}\right)}{\left(W_{\text {sat }}-W_{\text {subm }}\right)}$

where $W_{\text {sat }}$ is the mass ( $\mathrm{g}$ ) of the sample saturated with water (using a vacuum pump for replacing air in the voids with water); $W_{d r y}$ is the mass $(\mathrm{g})$ of the specimen after drying at $40{ }^{\circ} \mathrm{C}$ and cooling in a chemical desiccator; and $W_{\text {subm }}$ is the mass (g) of the sample in hydrostatic conditions (saturated and submerged in water). The measurements were carried out on the concrete discs, after the permeability tests.

\subsubsection{Chloride diffusion coefficient}

Chloride diffusion is involved in the corrosion of steel reinforcement embedded in the concrete cover and may cause a loss of durability of the structure. Resistance of concrete to chloride penetration has been largely investigated $[1,24,25]$. Since diffusion experiments are time-consuming, steady state migration tests were developed to accelerate chloride ions penetration through the concrete specimens.

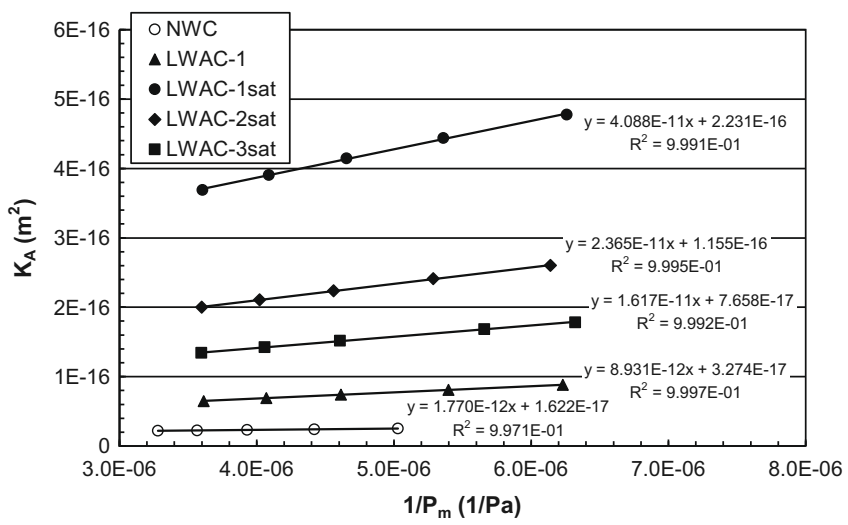

Fig. 4. Plotting of $K_{A}$ vs. $1 / P_{m}$.

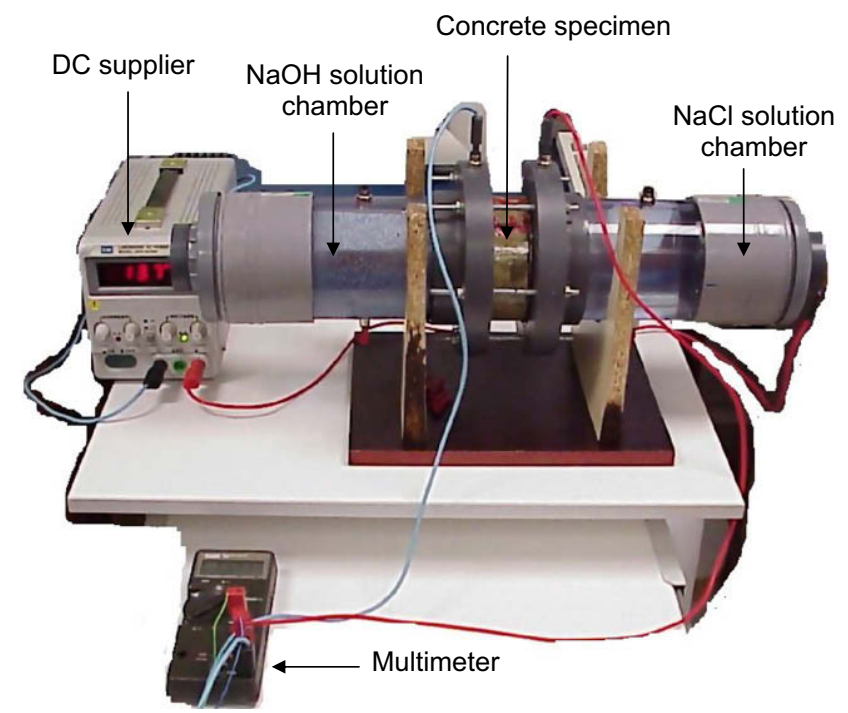

Fig. 5. Chloride ion migration cell.

Fig. 5 presents the chloride ion migration cell developed by Djerbi et al. [26] and used in the present study. After the gas permeability and porosity tests, each concrete disc was placed between two chambers containing solutions made with $\mathrm{NaOH}$ $(0.025 \mathrm{~mol} / \mathrm{L})$ and $\mathrm{KOH}(0.083 \mathrm{~mol} / \mathrm{L}) . \mathrm{NaCl}(0.513 \mathrm{~mol} / \mathrm{L})$ was added in the upstream solution and a $12-\mathrm{V}$ current is applied between the sides of the concrete sample. The test was carried out at $T=20 \pm 1^{\circ} \mathrm{C}$. As the flow becomes constant the effective chloride coefficient $D_{e}\left(\mathrm{~m}^{2} / \mathrm{s}\right)$ can be calculated using the modified Nernst-Planck's equation, as demonstrated in [27]. This equation neglects the diffusion and convection flows with respect to the electrical migration flow. Assuming very diluted solutions, it gives:

$D_{e}=\frac{R \cdot(T+273.15)}{Z \cdot F} \cdot \frac{L \cdot Q_{\left[\mathrm{Cl}^{-}\right]}}{\Delta E \cdot c_{0} t}$

where $c_{0}$ is the chloride concentration $\left(\mathrm{mol} / \mathrm{m}^{3}\right.$ ) of the catholyte solution (upstream compartment), assumed to be constant; $\mathrm{Q}_{\left[\mathrm{Cl}^{-}\right]}$is the cumulative amount of chloride ions $\left(\mathrm{mol} / \mathrm{m}^{2}\right)$ arriving in the downstream compartment during the time $t(\mathrm{~s}) ; L$ is the thickness of the specimen $(\mathrm{m}) ; z$ is the valence ion $(z=1) ; F$ is the Faraday constant $(F=96480 \mathrm{~J} / \mathrm{V}) ; E$ is the actual potential drop between the surfaces of specimen $(\mathrm{V})$; $R$ is the gas constant $(R=8.3144 \mathrm{~J} / \mathrm{mol} / \mathrm{K})$; and $T$ is the temperature $\left({ }^{\circ} \mathrm{C}\right)$.

The chloride concentration was determined by means of potentiometric titration with a Metrohm SA CH- 9101 Herisau automatic titrator with $0.05 \mathrm{M}$ silver nitrate $\left(\mathrm{AgNO}_{3}\right)$ titrant (Fig. 6).

\section{Result analysis}

\subsection{Workability and density}

\subsubsection{Slump test}

The slump value for each concrete mixture is shown in Table 4. The results were between 60 and $190 \mathrm{~mm}$. The replacement of or- 


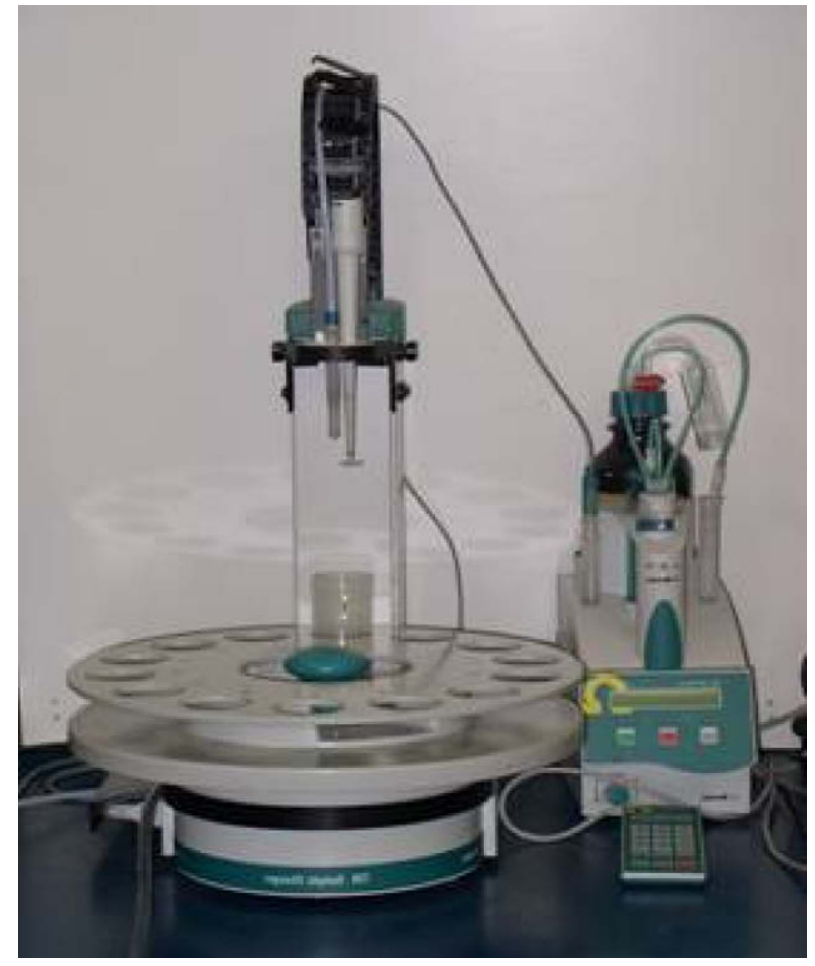

Fig. 6. Metrohm automatic titrator.

dinary aggregates (NWC mix) with dry lightweight aggregates (LWAC-1 mix) caused a large decrease in the slump value. This is explained by the high porosity of lightweight aggregates, which absorbs a significant amount of water and cement paste, reducing at the same time the workability of the mixture. Preliminary water saturation of the lightweight aggregates mitigated this loss of workability: indeed, the LWAC-1sat concrete showed a higher slump value than both the LWAC- 1 and NWC concretes. The gain of workability was related to the water initially contained in lightweight aggregates, which was partially incorporated in the cementitious matrix during the mixing and participated in the fluidify of the fresh material. To preserve the positive effect of lightweight aggregate pre-wetting, the LWAC-2sat and LWAC3-sat concretes were also manufactured with water-saturated PUR-foam aggregates. The slump values measured on these mixes were lower than that of LWAC-1sat mix: this difference was due to their lower W/C ratio, added to the higher cement content for LWAC-2sat mix and the higher PUR-foam aggregate amount in LWAC3-sat mix. The addition of superplasticizer was not very efficient in increasing or keeping the same level of workability than that of LWAC-1sat mix. Nevertheless, the proposed concrete proportioning enabled to obtain plastic concrete mixtures.

\subsubsection{Density}

Due to the lower density of the PUR-foam aggregates, the fresh density and the 28-day air-dried density of the concretes were significantly reduced. LWAC-1, LWAC-1sat, LWAC-2sat and LWAC-3sat mixes showed fresh densities equal to $1791 \mathrm{~kg} / \mathrm{m}^{3}$, $1779 \mathrm{~kg} / \mathrm{m}^{3}, 1776 \mathrm{~kg} / \mathrm{m}^{3}$ and $1656 \mathrm{~kg} / \mathrm{m}^{3}$, respectively. These values were $27-33 \%$ lower than the control concrete's density. After 28 days, the densities were $1699 \mathrm{~kg} / \mathrm{m}^{3}, 1679 \mathrm{~kg} / \mathrm{m}^{3}, 1678 \mathrm{~kg} / \mathrm{m}^{3}$ and $1538 \mathrm{~kg} / \mathrm{m}^{3}$ for LWAC-1, LWAC-1 sat, LWAC-2sat and LWAC3sat mixes, respectively. The PUR-foam aggregate concretes can thus be considered as lightweight concretes [28]. The density values decreased as foam proportioning increased. The pre-wetting of lightweight aggregates had a low influence on the fresh density of
LWAC: the difference between the densities of LWAC-1 and LWAC1 sat mixes was lower than $12 \mathrm{~kg} / \mathrm{m}^{3}$. The lower density of LWAC1 sat mix indicated that a certain amount of the water initially contained in LWA was incorporated in the cementitious matrix, causing a slight reduction of its density.

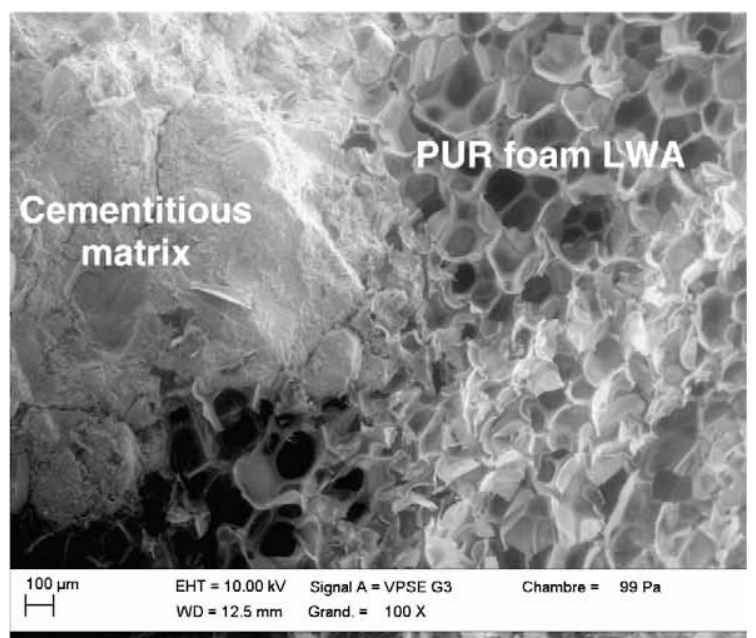

a. $\times 100$

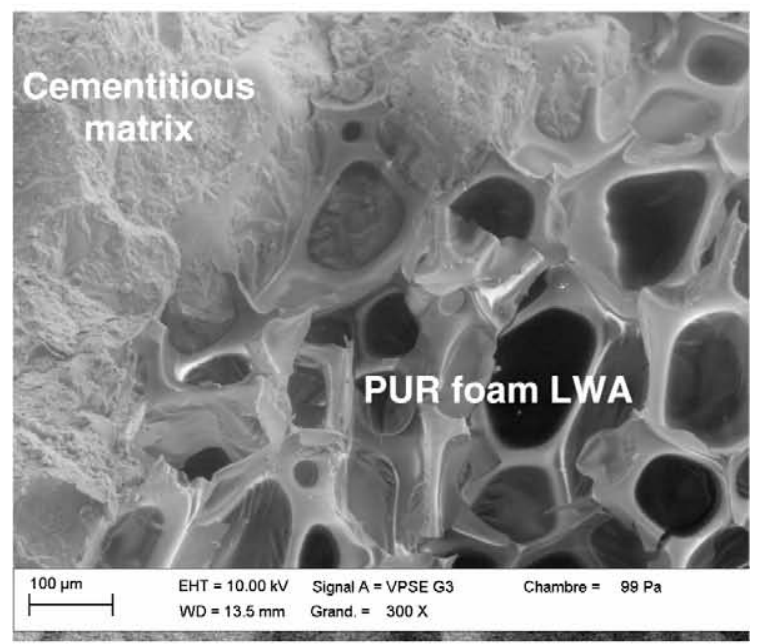

b. $\times 300$

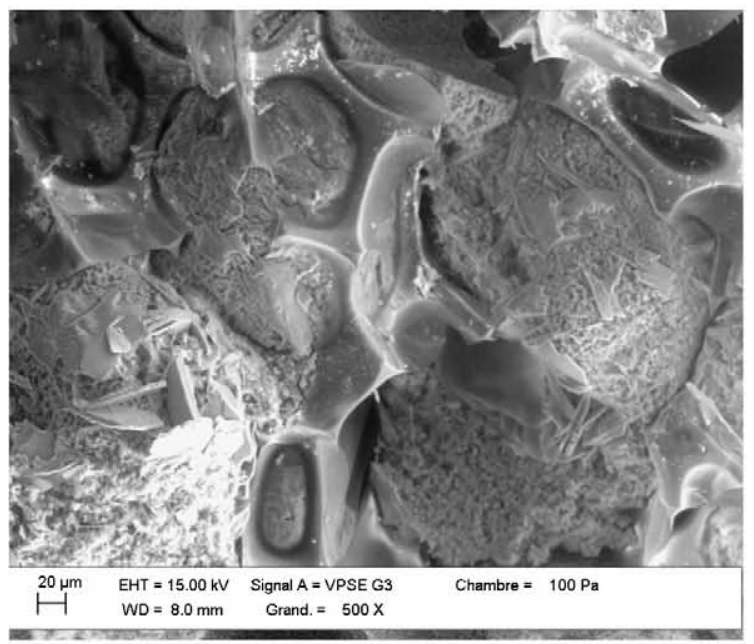

c. $\times 500$

Fig. 7. SEM micrographs of the interfacial zone between the cementitious matrix and the eight PUR-foam aggregates at 28 days (LWAC-1sat mix). 


\subsection{SEM observations of the microstructure}

Fig. 7 shows the microstructure of the mortar/PUR-foam aggregate interface of freshly fractured samples of LWAC. The samples used were obtained from fragments of cylindrical specimens tested in compression, and observed without any specific pre-treatment (drying or polishing). In cement-based composites, the interfacial zone (ITZ) usually influences in a significant way the mechanical behavior and the transfer properties of the material. The poor properties of this zone are generally related to two main phenomena: on the one hand, the "wall effect" occurring at the surface of normal weight aggregates and, on the other hand, the local accumulation of water under the aggregates in vibrated concrete (micro-bleeding). The first phenomenon induces a W/C-ratio gradient in the vicinity of coarse aggregates and the second phenomenon may lead to a certain heterogeneity of this W/C-ratio gradient around aggregates [29]. The characteristics of ITZ vary according to the type and porosity of aggregates, the porosity and bleeding of cement paste located around aggregates. For these reasons, ITZ in lightweight aggregate concretes is very different from that of the normal weight concretes [1]. Zhang and Gjørv [30] showed, on expanded clay aggregate concrete, that the porous surface of LWA improved the interfacial bond between aggregate and cement paste. They explained this phenomena by the interlocking sites provided by the rough surface of LWA, resulting in a dense and uniform interfacial zone with the cement-based mortar. Moreover, Lo and Cui [31] demonstrated that the 'wall effect' that appears in the normal weight concrete does not occur on the ITZ of LWAC. They estimated the resulting interfacial zone at about 5$10 \mathrm{~m}$ wide, which is much smaller than for normal aggregate.

Fig. 7 reveals a good adhesion between the cementitious matrix and the PUR-foam aggregates: the cement paste penetrated in the LWA surface porosity, which is sufficiently large for the cementitious microstructure to develop in it. For the observation scale considered, no "wall effect" was identified at the interface between prewetted or dry PUR-foam aggregate and cement mortar.

\subsection{Mechanical properties at 28 days}

\subsubsection{Compressive strength}

Fig. 8 gives the results of compressive strength tests at 28 days. The incorporation of PUR-foam aggregates caused a high reduction in the mechanical strength of concrete. At 28 days, the compressive strength of the lightweight concretes decreased from 57\% to $78 \%$ compared to the control concrete. Numerous studies already showed that the use of LWA induced a very significant decrease in the mechanical properties of concrete [32-35]. This was explained by the low mechanical properties and the high porosity of lightweight aggregates. It also should be noted that the rupture mechanism of the LWAC specimens was different from that of the NWC ones: in the case of LWAC, the rupture occured on the mortar matrix/LWA interfaces, but also in the middle of LWA, which constitutes the weak link of LWAC microstructures. In the case of NWC, the rupture mainly took place in ITZ because of the poor properties of this zone compared to the other concrete components.

Pre-wetting of the lightweight aggregates generates a decrease of compressive strength of $41 \%$ between LWAC- 1 and LWAC- 1 sat mixes. This observation seems to confirm the previous assumption according to which a part of the saturation water of LWA was incorporated within the cementitious matrix during the mixing phase. It resulted in an increase of the mortar porosity and thus a global reduction in the mechanical properties of concrete. This result is quite different from the mechanisms of internal curing, which enables to increase hydration and strength development by using saturated synthetic LWA made from expanded shale, clay or slate. However, this technique generally concerns cementitious systems with a low water-to-cement ratio (typically $\leqslant 0.40$ ) and consists in providing additional internal water for cement hydration [36]. In the present case, the initial $\mathrm{W} / \mathrm{C}$ ratio of concrete $(>0.50)$ is sufficient to complete the hydration of cement and the supplementary water supplied by the saturated PUR-foam aggregates only increases the porosity volume, with negative effects on mechanical resistance.

The comparison between LWAC-1sat, LWAC-2sat and LWAC3sat mixes showed the efficiency of using superplasticizer and decreasing the $\mathrm{W} / \mathrm{C}$ ratio for improving the mechanical properties of LWAC: in presence of superplasticizer, a $4.5 \%$ increase of cement content results in an increase by $26 \%$ of compressive strength. In the case of LWAC-3sat mix, the use of superplasticizer made it possible to decrease cement content by $15 \%$ and to increase PUR foam content by $33 \%$ compared to LWAC-1 sat mix, with an acceptable reduction (15\%) of compressive strength.

Fig. 9 presents the values of concrete compressive strength vs. their density. LWAC-1sat, LWAC-2sat and LWAC-3sat mixes exhibited too low mechanical properties compared to their density to be classified as moderate strength lightweight aggregate concretes. On the contrary, LWAC-1 mix, manufactured with dry LWA, almost satisfied the criteria of structural lightweight aggregate concrete as defined in ACI 318 and ASTM C 330. Indeed, ACI 318 requires that the structural LWAC (a) has a minimum compressive cylindrical strength at 28 days of $17 \mathrm{MPa}$, (b) has a corresponding air-dry unit weight not exceeding $1850 \mathrm{~kg} / \mathrm{m}^{3}$, and (c) consists of all LWA or a combination of LWA and normal weight aggregates. According to ASTM C 330, the LWA used in structural LWAC must have a bulk density less than $880 \mathrm{~kg} / \mathrm{m}^{3}$ for coarse aggregate, which is the case for PUR-foam aggregates.

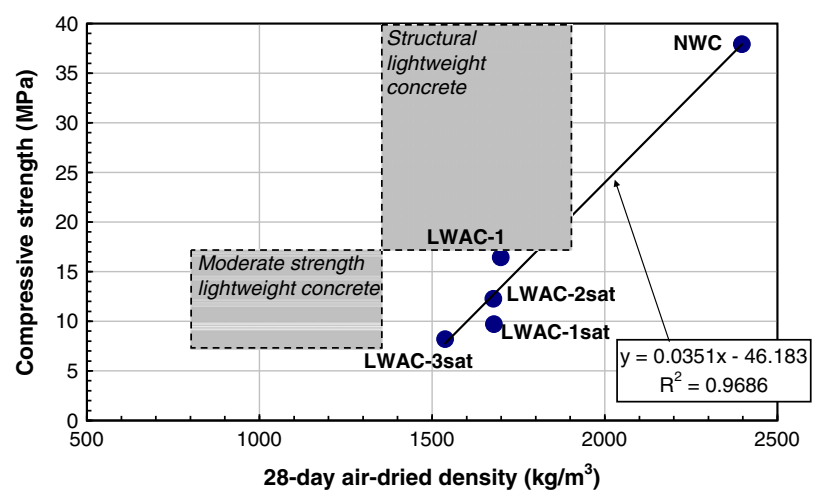

Fig. 9. Compressive strength vs. air-dried density of concretes at 28 days. 


\subsubsection{Dynamic modulus of elasticity}

As for compressive strength, the dynamic modulus of elasticity $(E)$ is affected by the presence of LWA, although the effect of LWA on $E$-values is generally less significant $[1,13,16,33]$. For example, Aamr-Daya et al. [13] showed that the use of $10 \%$ of flax by-products material in lightweight cement composite leads to a decrease of $67-77 \%$ of the compressive strength and $49 \%$ of the Young's modulus, compared to a composite without flax particles.

The values of the dynamic modulus of elasticity, measured on the concretes investigated, are plotted on Figs. 8 and 10 as a function of the air-dried density of concrete. It seems to exist an increasing linear correlation between dry density and dynamic modulus of elasticity. PUR foam is characterized by a low elastic modulus due to its high porosity; the increase of LWA content was then expected to reduce the $E$-values of LWAC. This reduction was from $59 \%$ to $69 \%$, compared to the $E$-value of control concrete.

Pre-wetting of PUR-foam aggregates does not significantly modify the value of the dynamic modulus of elasticity as shown by the small difference observed between the results obtained on LWAC- 1 and LWAC-1sat mixes. Moreover, improving the cementitious matrix properties by using superplasticizer and decreasing the $\mathrm{W} / \mathrm{C}$ ratio (LWAC-2sat mix), does not have influence on the value of $E$. Only an increase in PUR foam proportioning (LWAC-3sat mix) caused a considerable reduction in the dynamic modulus of elasticity of concrete.

\subsection{Moisture migration related properties: mass loss, porosity and drying shrinkage}

Mass loss measurements, plotted in Fig. 11, enable to estimate the intensity of moisture migration between concrete and its envi-

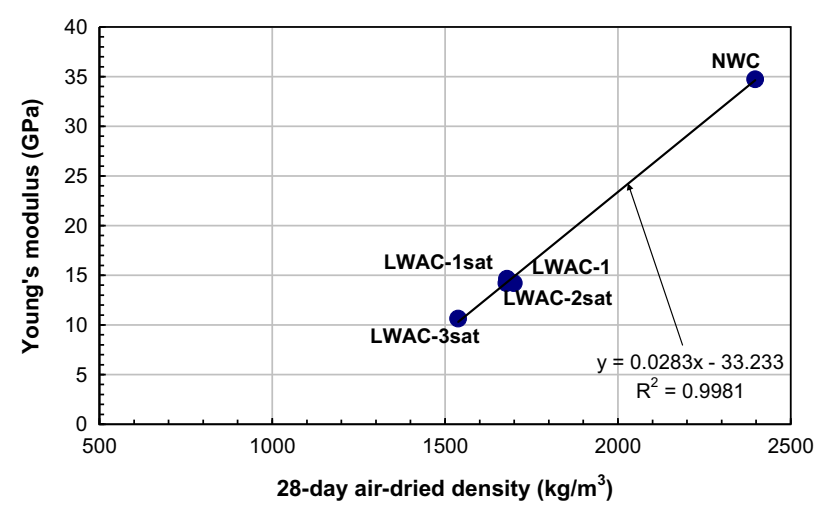

Fig. 10. Dynamic modulus of elasticity vs. air-dried density of concretes at 28 days.

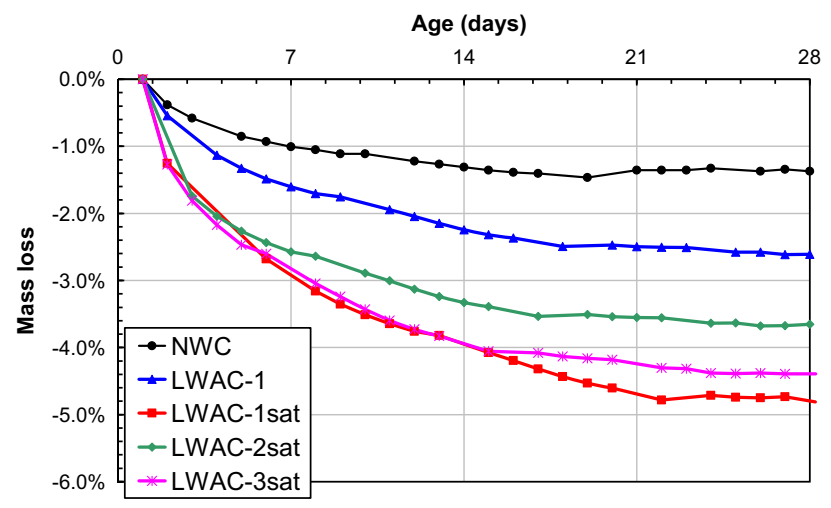

Fig. 11. Mass loss of the PUR-foam concrete mixtures $\left(T=20 \pm 2{ }^{\circ} \mathrm{C} ; R H=50 \pm 5 \%\right.$.
Table 5

Porosity and transfer properties of the concrete mixtures.

\begin{tabular}{lccl}
\hline Mix code & $\begin{array}{l}\text { Total porosity } \\
n(\%)\end{array}$ & $\begin{array}{l}\text { Permeability } \\
K_{V}\left(10^{-17} \mathrm{~m}^{2}\right)\end{array}$ & $\begin{array}{l}\text { Effective chloride coefficient } \\
D_{e}\left(10^{-12} \mathrm{~m}^{2} / \mathrm{s}\right)\end{array}$ \\
\hline NWC & 7.00 & 1.62 & 1.87 \\
LWAC-1 & 11.20 & 3.27 & 1.62 \\
LWAC-1sat & 17.32 & 22.30 & 5.30 \\
LWAC-2sat & 13.22 & 7.66 & 2.70 \\
LWAC-3sat & 18.12 & 11.50 & 5.98 \\
\hline
\end{tabular}

ronment. The mass losses of the different PUR-foam concretes were 1.9-3.5 times higher than that of the reference concrete. These important moisture transfers are related to the concrete porosity and the initial amount of water in the mixtures. Water was introduced as mixing water (which corresponds to the W/C ratio) and saturation water of LWA, which increased when PUR foam content grew. The greater porosity of LWAC (Table 5) facilitates and accelerates the diffusion of water and thus the mass loss of the material. The most porous concrete (LWAC3-sat mix), with richer PUR foam content, showed the higher 28-day mass loss (Fig. 11). These results can be compared to those of Saradhi Babu et al. [34], which highlighted, on water test absorption, that concretes with higher volume of lightweight aggregate showed higher moisture migration. They explained a part of this phenomena by possible micro-cracking caused by the shrinkage of low-density aggregate.

It should be noted that, in Fig. 11, the mass losses are expressed as percentages, i.e. they depend on the initial mass of each specimen. For the same amount of lost water, the mass loss in\% will be thus higher for the lightest concretes. Expressed in gram, the average mass losses at 28 days for a $7 \times 7 \times 28-\mathrm{cm}$ specimen were $45.00 \mathrm{~g}$ for NWC, $62.59 \mathrm{~g}$ for LWAC-1 mix, $117.16 \mathrm{~g}$ for LWAC1-sat mix, $89.05 \mathrm{~g}$ for LWAC2-sat mix and $108.75 \mathrm{~g}$ for LWAC3-sat mix. These mass losses are directly correlated to the porosity of concretes given in Table 5 . The replacement of normal weight aggregates (NWC mix) with lightweight aggregates (LWAC$1 \mathrm{mix}$ ), keeping the water content constant, caused a greater mass loss, related to the increase in porosity. Pre-wetting of LWA resulted in a mass loss nearly twice higher than in the case of concrete manufactured with dry LWA.

The moisture transfers usually induce dimensional variations of concretes. These length variations can generate early-age or longterm cracking, and thus a loss of durability of the concrete structure. Neville [28] indicated that the use of lightweight aggregate generally results in higher shrinkage, mainly due to the lower value of LWA elastic modulus [37]; Moreover, aggregates with high absorption properties are associated with high shrinkage in concrete [38]. This high absorption properties results in a higher demand for water and an increased water-to-cement ratio, leading to higher drying shrinkage deformations [2]. Drying shrinkage occurs due to the capillary tensile force induced as a result of water loss from the concrete. For the $\mathrm{W} / \mathrm{C}$ ratio range considered in the present study, drying shrinkage is largely predominant over autogenous shrinkage [39-41]. Strain measurements were then carried out on specimens used for the mass loss tests and subjected to drying in a room with $20 \pm 2{ }^{\circ} \mathrm{C}$ and $50 \pm 5 \%$. The drying shrinkage curves plotted in Fig. 12 show that LWAC1, LWAC1-sat, LWAC2sat and LWAC3-sat mixes exhibited 28-day drying shrinkage values $8.1 \%, 72.5 \%, 49.7 \%$ and $149.5 \%$ higher than that of the control concrete, respectively. The concrete with the higher LWA content (LWAC-3sat) developed the higher shrinkage values. As discussed above, this greater shrinkage is a consequence of the low elastic modulus of LWA: these latter shrink more than normal weight aggregates when subjected to similar capillary tension stress. This explains the very high shrinkage values recorded on LWAC-3sat 


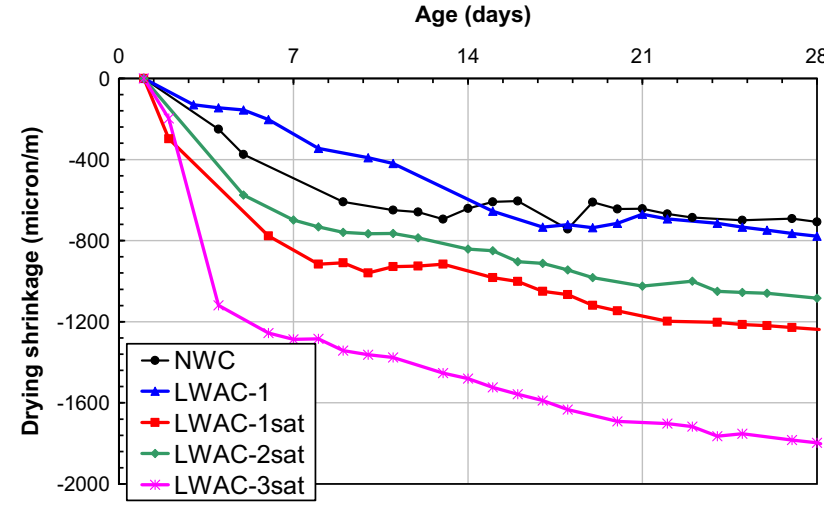

Fig. 12. Drying shrinkage of the PUR-foam concrete mixtures $5\left(T=20 \pm 2{ }^{\circ} \mathrm{C}\right.$; $R H=50 \pm 5 \%$.

mix, which contained a LWA volume much more important than the other LWAC investigated. Besides, pre-wetting of LWA introduced additional water into the mixture, leading to higher porosity and moisture migration (Fig. 11). For the same composition of cementitious matrix, an increase of LWA content resulted in higher pre-wetting water amount and in greater shrinkage strains. This explains the higher shrinkage of LWAC-1sat concrete, manufactured with prewetted PUR-foam aggregates, compared to LWAC$1 \mathrm{mix}$, prepared with dry aggregates (Fig. 12). It was possible to limit this increase in drying shrinkage by simultaneously decreasing the $\mathrm{W} / \mathrm{C}$ ratio and increasing sand and cement contents, as shown by the results obtained on LWAC-2sat mix. Indeed, in spite of a slightly higher PUR foam content, drying shrinkage of this concrete was $13.3 \%$ lower than that observed on LWAC-1sat mix.

\subsection{Transfer properties}

\subsubsection{Gas permeability}

Table 5 gives the values of gas permeability obtained on the five concrete mixtures investigated. The substitution of normal weight aggregates (NWC mix) with PUR-foam aggregates (LWAC-1 mix) multiplied by two the gas permeability of concrete. This ratio is comparable to those available in the few studies carried out in the field and recapitulated in Table 6 . Considering both constant mortar composition and coarse aggregate volume, Sugiyama et al. [25] obtained a gas permeability of lightweight concretes 1.7-1.9 times higher than that of normal concretes. Zakaria and Cabrera [42] determined the gas permeability of LWAC made with crushed brick and fly ash-clay aggregates and found these permeabilities were 2.2 and 2.7 times higher than the permeability of an ordinary concrete made with the same volume proportion of cement, water and aggregate. Noumowé et al. [43] carried out a comparative study on the gas permeability of various concretes, including a high performance concrete and a lightweight aggregate concrete with identical cementitious matrix and aggregate propor-

Table 6

Bibliographical data on gas permeability of lightweight aggregate concretes.

\begin{tabular}{|c|c|c|c|c|c|}
\hline References & $\begin{array}{l}\text { Gas } \\
\text { used }\end{array}$ & $\begin{array}{l}\text { Type of } \\
\text { lightweight } \\
\text { aggregates }\end{array}$ & $\begin{array}{l}\text { Fresh } \\
\text { density } \\
(\mathrm{kg} / \\
\left.\mathrm{m}^{3}\right)\end{array}$ & $\begin{array}{l}\text { Water/ } \\
\text { binder } \\
\text { ratio } \\
(-)\end{array}$ & $\begin{array}{l}\text { Intrinsic } \\
\text { permeability } \\
\left(10^{-17} \mathrm{~m}^{2}\right)\end{array}$ \\
\hline \multirow[t]{2}{*}{ [25] } & \multirow[t]{2}{*}{ Nitrogen } & Expanded & 1837 & 0.40 & 13.8 \\
\hline & & shale & 1934 & 0.60 & 14.4 \\
\hline \multirow[t]{2}{*}{ [42] } & \multirow[t]{2}{*}{ Oxygen } & Crushed brick & - & 0.55 & 3.0 \\
\hline & & Fly ash-clay & - & 0.55 & 3.8 \\
\hline [43] & Nitrogen & Expanded clay & 1930 & 0.30 & 33.0 \\
\hline
\end{tabular}

tionning. At $20^{\circ} \mathrm{C}$, they measured a gas permeability of LWAC 2.2 times higher than that of concrete manufactured with normal weight aggregates.

Moreover, it was observed that pre-wetting of aggregates caused a large increase in gas permeability (Table 5). As for mechanical properties and drying shrinkage, the reduction in $\mathrm{W} / \mathrm{C}$ ratio (LWAC-2sat mix) enabled to reduce the negative effects of pre-wetting on gas permeability.

It should be noted that, among the concrete investigated, the most porous concrete did not have the higher gas permeability. Indeed, the LWAC-3sat mix, with a porosity of $18.12 \%$, was less permeable than the LWAC-1sat mix, whose porosity is equal to $17.32 \%$. The transfer of gas through a porous medium is a combination of flow passing through the cementitious matrix and the lightweight aggregates. In this flow distribution, the pore volume is not the only parameter conditioning mass transfers. Both the organization and connectivity of the porous network and the pore diameter are also involved in mass flow through the medium [44]. From this point of view, the reduction in $\mathrm{W} / \mathrm{C}$ ratio resulted in decreasing the porosity and thus the permeability of the continuous phase, i.e. the cementitious matrix. Moreover, the increase in LWA volume induced both an increase in closed porosity and a reduction in the volume of mortar matrix through which the gas circulates. Thus by modifying the composition of the cementitious phase and by increasing LWA content, it was possible to decrease at the same time the gas permeability and the density of concrete.

\subsubsection{Chloride diffusion coefficient}

The chloride diffusion coefficients of the concretes studied are recapitulated in Table 5 . A difference of $-13 \%, 183 \%, 44 \%$ and $220 \%$ was recorded between the diffusion coefficient of NWC concrete and those of LWAC-1, LWAC-1sat, LWAC-2sat and LWAC-3sat mixes, respectively. The substitution of normal aggregates with LWA did not involve a modification of ionic transfer as significant as that noted on gas permeability: NWC and LWC-1sat mixes showed relatively close values of chloride diffusion coefficient. This result is in agreement with those reported in literature. According to Zhang and Gjørv [24], the use of LWA in concrete does not inevitably mean higher penetration of chloride ions. Sugiyama et al. [25] and Chia and Zhang [44] reported similar values of chloride penetration rates for lightweight and normal weight concretes with equal $\mathrm{W} / \mathrm{C}$ ratios. According to them, the denser outer layer of the LWA used and a high-quality mortar-LWA interfacial zone may limit the penetration of chloride ions into LWAs.

As shown in Table 5, the pre-saturation in water of LWA resulted in a significant increase of the chloride diffusion coefficient. This effect, already highlighted on gas permeability measurements, indicates a higher porosity of the cementitious matrix. The properties of the cementitious matrix play a predominant role on mass transfers in LWAC $[24,25]$. By comparing penetration rate of chloride ions in various LWAC, Zhang and Gjørv [24] observed that the ionic diffusion within these concretes was mainly conditioned by the mortar matrix composition and by ITZ properties. According to them, there exists an optimum value of cement content enabling to minimize chloride diffusion. According to the results obtained here, a reduction in $\mathrm{W} / \mathrm{C}$ ratio and an increase in cement proportioning (LWAC-2sat mix) made it possible to significantly decrease the effect of LWA pre-wetting.

\section{Conclusions}

This study investigates the valorization of polyurethane foam waste as low-density aggregates for the manufacture of lightweight concretes. The effects of an incorporation of PUR foam 
waste on the fresh and hardened properties of concrete have been analyzed.

The following main conclusions can be drawn:

- The feasibility of making lightweight aggregate concrete with PUR foam waste has been proved. These concretes showed a good workability, which was improved when using prewetted PUR-foam aggregates.

- Increasing the amount of PUR foam LWA led to higher porosity of concretes, which facilitates moisture exchange with the environment and increases drying shrinkage, gas permeability and chloride diffusion coefficient in saturated conditions.

- Improving the properties of the cementitious matrix by lowering the $\mathrm{W} / \mathrm{C}$ ratio and adding superplasticizer enabled to reduce the effects of lightweight aggregates on concrete's transfer properties.

- The lightweight concretes showed compressive strength ranging between 8 and $16 \mathrm{MPa}$ and dynamic modulus of elasticity ranging between 10 and $15 \mathrm{GPa}$. The reduction in mechanical properties, compared to normal weight concrete, can be directly connected to the increase in PUR foam content and the amount of mixing water. However, concrete manufactured with dry PUR foam LWA, almost satisfied the criteria of structural LWAC.

These results consolidate the idea of using PUR foam waste for the manufacture of lightweight aggregate concretes. The use of these "low cost" LWA may help to reduce the cost per unit volume of LWAC. In order to evaluate the economical benefit on the production of LWAC, further research work will aim at comparing and analyzing the cost/performance ratios of concretes prepared with different types of LWA (expanded polystyrene sphere, expanded clay, plastic waste).

\section{Acknowledgement}

The authors would like to acknowledge the technical help provided by M. Adnan Boukhouna for the determination of chloride ion diffusion coefficients.

\section{References}

[1] Kayali O. Fly ash lightweight aggregates in high performance concrete. Constr Build Mater 2008;22(12):2393-9.

[2] Alduaij J, Alshaleh K, Haque MN, Ellaithy K. Lightweight concrete in hot coastal areas. Cem Concr Compos 1999;21(5-6):453-8.

[3] Qiao XC, Ng BR, Tyrer M, Poon CS, Cheeseman CR. Production of lightweight concrete using incinerator bottom ash. Constr Build Mater 2008;22(4):473-80.

[4] Siddique R, Naik TR. Properties of concrete containing scrap tire rubber-an overview. Waste Manage 2004;24(6):563-9.

[5] Batayneh MK, Marie I, Asi I. Promoting the use of crumb rubber concrete in developing countries. Waste Manage 2008;28(11):2171-6.

[6] Khaloo AR, Dehestani M, Rahmatabadi P. Mechanical properties of concrete containing a high volume of tire-rubber particles. Waste Manage 2008;28(12):2472-82.

[7] Kou SC, Lee G, Poon CS, Lai WL. Properties of lightweight aggregate concrete prepared with PVC granules derived from scraped PVC pipes. Waste Manage 2009;29(2):621-8.

[8] Panyakapo P, Panyakapo M. Reuse of thermosetting plastic waste for lightweight concrete. Waste Manage 2008;28(9):1581-8.

[9] Ismail ZZ, Al-Hashmi EA. Use of waste plastic in concrete mixture as aggregate replacement. Waste Manage 2008;28(11):2041-7.

[10] Anagnostopoulos IM, Stivanakis VE. Utilization of lignite power generation residues for the production of lightweight aggregates. J Hazard Mater 2009;163(1):329-36.

[11] Coatanlem P, Jauberthie R, Rendell F. Lightweight wood shipping concrete durability. Constr Build Mater 2006;20(9):776-81.
[12] Teo DCL, Mannan MA, Kurian VJ, Ganapathy C. Lightweight concrete made from oil palm shell (OPS): structural bond and durability properties. Build Environ 2007;42(7):2614-21.

[13] Aamr-Daya E, Langlet T, Benazzouk A, Quéneudec M. Feasibility study of lightweight cement composite containing flax by-product particles: physicomechanical properties. Cem Concr Compos 2008;30(10):957-63.

[14] Segre N, Joekes I. Use for tire rubber particles as addition to cement paste. Cem Concr Res 2000;30(9):1421-5.

[15] Wang X, Jin Y, Wang Z, Nie Y, Huang Q, Wang Q. Development of lightweight aggregate from dry sewage sludge and coal ash. Waste Manage 2009;29(4):1330-5.

[16] Siddique R, Khatib J, Kaur I. Use of recycled plastic in concrete: a review. Waste Manage 2008;28(10):1835-52.

[17] Hilyard NC, Kinder AI, Axelby GL. A techno-economic study of the disposal of polyurethane foam waste by incineration and heat recovery. Cell Polym 1985;4:367-84.

[18] Gutt W, Nixon PJ. Use of waste materials in the construction industry. Mater Struct 1979;12:255-306.

[19] Boser R, Ragsdale T, Duvel C. Recycled foam and cement composites in insulating concrete forms. J Ind Tech 2002;18:1-5.

[20] Perevozchikov A, Yakovlev G, Kodolov V. Polyethylene foam waste utilization for lightweight concrete production. Int J Polym Mater 2000;47:7-17.

[21] Laukaitis A, Žurauskas R, Kerienè J. The effect of foam polystyrene granules on cement composite properties. Cem Concr Compos 2005;27(1):41-7.

[22] Mounanga P, Gbongbon W, Poullain P, Turcry P. Proportioning and characterization of lightweight concrete mixtures made with rigid polyurethane foam wastes. Cem Concr Compos 2008;30(9):806-14.

[23] Picandet V, Khelidj A, Bastian G. Effect of axial compressive damage on gas permeability of ordinary and high-performance concrete. Cem Concr Res 2001;31(11):1525-32.

[24] Zhang M-H, Gjørv OE. Permeability of high strength lightweight concrete. ACI Mater J 1991;88:463-9.

[25] Sugiyama T, Bremner TW, Tsuji Y. Determination of chloride diffusion coefficient and gas permeability of concrete and their relationship. Cem Concr Res 1996;26(5):781-90.

[26] Djerbi A, Bonnet S, Khelidj A, Baroghel-Bouny V. Influence of traversing crack on chloride diffusion into concrete. Cem Concr Res 2008;38(6):877-83.

[27] Andrade C. Calculation of chloride diffusion coefficients in concrete from ionic migration measurements. Cem Concr Res 1993;23(3):724-42.

[28] Neville AM. Properties of concrete. 4th ed. Essex (England): Addison Wesley Longman; 1997.

[29] Ollivier JP, Maso JC, Bourdette B. Interfacial transition zone in concrete. Adv Cem Based Mater 1995;2(1):30-8.

[30] Zhang M-H, Gjørv OE. Microstructure of the interfacial zone between lightweight aggregate and cement paste. Cem Concr Res 1990;20(4):610-8.

[31] Lo TY, Cui HZ. Effect of porous lightweight aggregate on strength of concrete. Mater Lett 2004;58(6):916-9.

[32] Al-Khaiat H, Haque MN. Effect of initial curing on early strength and physical properties of a lightweight concrete. Cem Concr Res 1998;28(6):859-66.

[33] Chi JM, Huang R, Yang CC, Chang JJ. Effect of aggregate properties on the strength and stiffness of lightweight concrete. Cem Concr Compos 2003;25(2):197-205.

[34] Saradhi Babu D, Ganesh Babu K, Wee TH. Effect of polystyrene aggregate size on strength and moisture migration characteristics of lightweight concrete. Cem Concr Compos 2006;28(6):520-7.

[35] Torres ML, García-Ruiz PA. Lightweight pozzolanic materials used in mortars: evaluation of their influence on density, mechanical strength and water absorption. Cem Concr Compos 2009;31(2):114-9.

[36] Bentz DP, Lura P, Roberts JW. Mixture proportioning for internal curing. Concr Int 2005;27(2):35-40.

[37] Chen B, Liu J. Properties of lightweight expanded polystyrene concrete reinforced with steel fiber. Cem Concr Res 2004;34(7):1259-63.

[38] Hossain KMA. Properties of volcanic pumice based cement and lightweight concrete. Cem Concr Res 2004;34(2):283-91.

[39] Kohno K, Okamoto T, Isikawa Y, Sibata T, Mori H. Effects of artificial lightweight aggregate on autogenous shrinkage of concrete. Cem Concr Res 1999;29(4):611-4.

[40] Ding Q, Tian Y, Wang F, Zhang F, Hu S. Autogenous shrinkage of high strength lightweight aggregate concrete. J Wuhan Univ Technol 2005;20:123-5.

[41] Mounanga P, Baroghel-Bouny V, Khelidj A, Loukili A. Autogenous deformations of cement pastes-part I: temperature effects at early age and micro-macro correlations. Cem Concr Res 2006;36(1):110-22.

[42] Zakaria M, Cabrera JG. Performance and durability of concrete made with demolition waste and artificial fly ash-clay aggregates. Waste Manage 1996;16(1-3):151-8.

[43] Noumowé AN, Siddique R, Debicki G. Permeability of high-performance concrete subjected to elevated temperature $\left(600^{\circ} \mathrm{C}\right)$. Constr Build Mater 2009;23(5):1855-61.

[44] Chia KS, Zhang M-H. Water permeability and chloride penetrability of highstrength lightweight aggregate concrete. Cem Concr Res 2002;32(4):639-45. 